УДК 504.054.87.15.15:504.064:36

Olena V. Barabash, PhD (Biology), Associate Professor

e-mail: el_barabash@ukr.net

National Transport University, Kyiv, Ukraine

\title{
ASSESSMENT OF THE ECOLOGICAL SAFETY LEVEL IN THE URBAN ECOSYSTEM BY THE ATMOSPHERIC AIR CONDITION
}

\begin{abstract}
Green plantings, which are a part of the modern city, are an important element creating an environment providing favorable microclimatic and sanitary conditions for human living. Plants of the city streets, which tend to grow near the roadway, play an important role. According to the magnitude of the fluctuation asymmetry of the bilateral morphological features in plant organisms, the main environmental hazards resulting from the complex of emission, backgroundparametric and landscape-destructive effects associated with the formation of the urban landscape were investigated. It is proposed to determine the state of the urban ecosystem based on the of fluctuation asymmetry (FA) criteria - slight nondirectional deviations between the sides of the organ, which are laid during ontogeny. The condition of the small-leaved linden (Tilia cordata) leaf plates was evaluated by the development stability, which characterizes the level of pollution in the urban ecosystem. The nature of industrial emissions into the air basin and water bodies was analyzed, as well as the level of the soil cover contamination due to the deposition of aerosol emissions in the administrative districts of Kyiv. A comprehensive approach was proposed to evaluate the status of urban ecosystems based on the combination of instrumental methods with bioindication research methods. Such a combination will make it possible to classify urban areas with the high probability, first, not by the degree of chemical pollution, but by the degree of anthropogenic changes in a whole set of environmental factors, which play a crucial role in the formation of specific properties of the urban ecosystem.
\end{abstract}

Keywords: fluctuation asymmetry; developmental stability; small-leaved linden (Tilia cordata); dendroindication, urban ecosystem

\section{O.B. Барабаш}

Національний транспортний університет, м. Київ, Україна

\section{ОЦНКА РІВНЯ ЕКОЛОГІЧНОЇ БЕЗПЕКИ УРБОЕКОСИСТЕМ ЗА СТАНОМ АТМОСФЕРНОГО ПОВІТРЯ}

\begin{abstract}
Анотація. 3 в величиною флуктуаційної асиметрії білатеральних морфологічних ознак рослинних організмів проведено дослідження основних екологічних небезпек, що виникають в результаті комплексу емісійних, фоново-параметричних та ландшафтно-деструктивних впливів, пов'язаних із формуванням міського ландшафту. Запропоновано визначати ступінь збереження екологічних властивостей урбоекосистеми на основі критеріїв флуктуаційної асиметрії (ФА) - незначних ненаправлених відхилень між сторонами органу, які закладаються під час онтогенезу. Проведено оцінку стану листкових пластинок липи сериелистої (Tilia cordata) за стабільністю розвитку, що характеризує рівень забруднення урбоекосистеми. Проаналізовано характер промислових викидів в повітряний басейн та водні об' 'єкти, а також з'ясовано рівень забруднення трунтового покриву внаслідок
\end{abstract}


осадження аерозольних викидів на території адміністративних районів м. Києва. Запропоновано комплексний підхід для оцінки стану урбоекосистем на основі поєднання інструментальних методів з методами біоіндикаційних досліджень. Таке поєднання дозволить із найбільшою долею вірогідності класифікувати міські території, в першу чергу, не за ступенем хімічного забруднення, а за ступенем антропогенних змін иілого комплексу екологічних факторів, які відіграють вирішальну роль у формуванні специфічних властивостей урбоекосистеми.

Ключові слова: флуктуачійна асиметрія; стабільність розвитку; липа сериелиста (Tilia cordata); дендроіндикаиія; урбоекосистема

\section{Вступ}

В умовах сьогодення досить актуальною виявляється комплексна оцінка рівня забруднення урбоекосистеми, зокрема іiі компонентів. Оцінка рівня екологічної безпеки компонентів урбоекосистем є необхідним інструментом для зменшення загроз здоров'ю населення міст в результаті емісії пилу в атмосферу та надходження забруднюючих речовин у грунти, водні об'єкти та їх ресурси. Комплексна оцінка екологічної безпеки урбоекосистеми полягає у поєднанні методів біоіндикації із визначенням основних видів діяльності промислових підприємств та їх впливу на стан навколишнього природного середовища за допомогою інструментальних методів.

Основними джерелами забруднення в умовах міста як урбоекосистеми $є$ промислові підприємства й автомобільний транспорт, в результаті цього резистентність рослинних організмів до абіогенних стресорів істотно знижується, що призводить до анатомо-морфологічних флуктуацій їх вегетативних та генеративних органів. Для оцінки стабільності розвитку деревних рослинних насаджень застосовують критерії флуктуаційної асиметрії (ФА), які виявляють незначні відмінності між правою і лівою сторонами листкової пластинки, що закладаються під час онтогенезу. При задовільному стані навколишнього середовища їх рівень мінімальний, коли ж негативний вплив збільшується, проявляється асиметрія [1].

Рівень флуктуаційної асиметрії морфологічних структур може використовуватися як неспецифічний стрес-індикатор, що відображає деформацію взаємодій між організмом та навколишнім середовищем [2] і $€$ коректним способом формалізації ступеня відхилення розвитку особини і навіть популяції від норми. Моніторинг таких проявів дестабілізації, які відбуваються під час онтогенезу рослинних організмів, може надати інформацію про негативні біотичні або абіотичні чинники, наявність антропогенного тиску [3]. Отримана інформація щодо стабільності розвитку деревних насаджень у поєднанні з результатами фіксованих вимірювань викидів забруднюючих речовин дозволить не лише визначити стан природних ресурсів, але й розробити стратегію збалансованого розвитку регіонів, вирішити питання щодо контролю діяльності стаціонарних джерел забруднення, провести оцінку результативності природоохоронних заходів 3 охорони атмосферного повітря тощо. Отже, застосування інструментальних методів із біоіндикаційними дослідженнями під час виявлення впливу виробничих потужностей підприємств на стан навколишнього природного середовища дозволить отримати об'єктивні результати і провести кількісну та якісну оцінку компонентів урбоекосистеми для встановлення заходів щодо їх відновлення. 
В роботах багатьох науковців досліджено та представлено вирішення питань щодо значення екологічного моніторингу для забезпечення екологічної безпеки, визначено сфери і напрямки моніторингу, розглянуто показники оцінки та методи і засоби його проведення [4, 5]. У наукових роботах Clarke G. [6], Franiel I. [7], Loehle C. [8], Sakai K., Shimamoto Y. [9] висвітлено підходи щодо застосування та ретельного вибору чутливих та інформаційних біоіндикаторів. Незважаючи на велику кількість робіт, які певним чином стосуються проблем застосування методів біоіндикації, питання комплексної оцінки рівня екологічної безпеки урбоекосистем вимагають спеціальної уваги та проведення додаткових досліджень.

Метою роботи $\epsilon$ дослідження та оцінка якості урбоекосистеми за стабільністю розвитку деревних насаджень в умовах антропогенного тиску.

\section{Матеріал і результати досліджень}

Збір матеріалу проводився відповідно до методики оцінки стану організмів за показниками порушення стабільності розвитку [10]. Матеріалом досліджень обрано листкові пластинки T. cordata, відібрані після зупинки росту листя (в кінці серпня 2019 р.). Кожна вибірка складалася зі 100 листкових пластинок (по 10 листків $з$ одного дерева), які були взяті з нижньої частини крони дерева, на рівні піднятої руки, з максимальної кількості доступних гілок, рівномірно навколо дерева. При зборі листя враховували його розмір і функціональний стан.

Для оцінки величин ФА, згідно з існуючою методикою [10], досліджено 5 білатеральних ознак: 1 - ширина лівої і правої половинок листка; 2 - відстань від основи до кінця жилки другого порядку, другої від основи листка; 3 відстань між основами першої і другої жилок другого порядку; 4 - відстань між кінцями першої і другої жилок другого порядку; 5 - кут між головною жилкою і другою від основи листка жилкою другого порядку.

Для замірів лівої і правої половинок листкової пластинки використовували циркуль-вимірювач, лінійку i транспортир. Інтегральний показник ФА розраховували таким чином: 1) для кожної листкової пластинки обчислювали відносні величини асиметрії для кожної ознаки (різницю між промірами зліва (L) i праворуч (R) ділили на суму цих замірів: $(\mathrm{L}-\mathrm{R}) /(\mathrm{L}+\mathrm{R}) ; 2$ ) обчислювали показник асиметрії для кожного листка (додавали значення відносних величин асиметрії за кожною ознакою і ділили на число ознак); 3) обчислювали інтегральний показник стабільності розвитку - величину середньої відносної відмінності між сторонами на ознаку (обчислювали середнє арифметичне всіх величин асиметрії (для кожного 3 десяти дерев). Статистичну обробку отриманого матеріалу проводили за допомогою стандартного пакету програми MS Excel.

Для оцінки ступеня виявлених відхилень від норми використовували бальну шкалу, що характеризує рівень забруднення території на основі показника ФА. Значення інтегрального показника асиметрії, які відповідають першому балу, зазвичай спостерігаються у вибірках рослин сприятливих умов зростання, наприклад в природних заповідниках. П’ятий бал - критичне значення (такі дані показника асиметрії спостерігаються у вкрай несприятливих умовах, коли рослина перебуває в сильно пригніченому стані). 
Зростання населення і промислового виробництва у м. Києві зумовило інтенсивне індустріальне, житлово-комунальне та соціально-культурне будівництво, розширення транспортної та енергетичної мереж міста. Через нарощування промислово-енергетичного i транспортного потенціалів в Київському мегаполісі антропогенне навантаження на атмосферне повітря, грунтовий покрив, водні об'єкти та їх ресурси призвело до формування специфічної трансформованої урбоекосистеми, де фізико-хімічні властивості та хімічний склад компонентів біосфери модифікуються й частково втрачають свої основні функції, такі як: забезпечення належного життєвого простору для грунтової біоти і рослинних організмів, формування захисного екрана для екосистеми, забезпечення груп біоти поживними речовинами і здатності до депонації та трансформації токсичних сполук у більш безпечні їх форми. Всі ці зміни у компонентах біосфери урбоекосистеми пов'язані 3 діяльністю стаціонарних та пересувних джерел забруднення, які, впливаючи на міське середовище, змінюють його, надаючи нових характеристик.

Київ поділяється на десять адміністративних міських районів, утворених за радіальним принципом (Печерський, Шевченківський, Подільський, Солом'янський, Дніпровський, Деснянський, Оболонський, Голосіївський, Святошинський, Дарницький), у яких за даними фіксованих вимірювань спостерігається нерівномірність забруднення, а основними джерелами забруднення цих районів є підприємства енергетичного комплексу та хімічної промисловості (табл. 1).

Таблиця 1 - Вплив діяльності стаціонарних джерел забруднення на стан компонентів урбоекосистеми

\begin{tabular}{|c|c|c|c|c|}
\hline \multirow[t]{2}{*}{ № } & \multirow[t]{2}{*}{$\begin{array}{c}\text { Район } \\
\text { дослідження }\end{array}$} & \multicolumn{3}{|c|}{$\begin{array}{c}\text { Перевищення по основних забруднюючих речовинах } \\
\text { (дані фіксованих вимірювань) }\end{array}$} \\
\hline & & $\begin{array}{l}\text { Атмосферне } \\
\text { повітря }\end{array}$ & Водні об'єкти & $\begin{array}{l}\text { Грунтовий } \\
\text { покрив }\end{array}$ \\
\hline 1 & Голосіївський & $\begin{array}{c}\mathrm{CH}_{2} \mathrm{O}, \mathrm{SO}_{2}, \mathrm{NO}_{2}, \\
\mathrm{TY}\end{array}$ & Завислі речовини & Нафтопродукти \\
\hline 2 & Оболонський & $\mathrm{SO}_{2}, \mathrm{NO}_{2}$ & Завислі речовини & Нафтопродукти \\
\hline 3 & Шевченківський & $\mathrm{CO}, \mathrm{SO}_{2}$ & Завислі речовини & Нафтопродукти \\
\hline 4 & Дарницький & $\begin{array}{c}\mathrm{SO}_{2}, \mathrm{NO}_{2}, \mathrm{~T} \Psi \\
\mathrm{CO}\end{array}$ & $\begin{array}{c}\text { Завислі речовини, } \\
\mathrm{SO}_{4}{ }^{2-}, \mathrm{Cl}^{-}, \mathrm{NO}^{3-}, \mathrm{PO}_{4}{ }^{3-}, \\
\mathrm{Mn}, \mathrm{Fe}, \mathrm{NO}^{2-}, \mathrm{NH}_{4}{ }^{+}\end{array}$ & $\begin{array}{c}\mathrm{Hg}, \mathrm{Pb}, \mathrm{Zn}, \mathrm{Cr}, \mathrm{Ni}, \\
\mathrm{Cu}, \mathrm{Ba}, \mathrm{V}, \mathrm{W}, \mathrm{Mn}, \\
\text { нафтопродукти }\end{array}$ \\
\hline 5 & Дніпровський & $\begin{array}{l}\mathrm{CO}, \mathrm{SO}_{2}, \mathrm{NO}_{2} \\
\mathrm{T \Psi}\end{array}$ & $\begin{array}{l}\mathrm{SO}_{4}^{2-}, \mathrm{Cl}^{-}, \text {завислі } \\
\text { речовини, } \mathrm{Cu}, \mathrm{NH}_{4}^{+}\end{array}$ & $\begin{array}{c}\mathrm{Hg}, \mathrm{Pb}, \mathrm{Zn}, \mathrm{Cr}, \mathrm{Ni} \text {, } \\
\mathrm{Cu}, \mathrm{Ba}, \mathrm{V}, \mathrm{W}, \mathrm{Mn} \text {, } \\
\text { нафтопродукти }\end{array}$ \\
\hline 6 & Деснянський & $\mathrm{SO}_{2}$ & $\begin{array}{c}\mathrm{SO}_{4}^{2-}, \mathrm{Cl}^{-}, \text {завислі } \\
\text { речовини, } \mathrm{Cu}, \mathrm{NH}_{4}^{+}\end{array}$ & Нафтопродукти \\
\hline 7 & Печерський & $\mathrm{CO}, \mathrm{SO}_{2}$ & Завислі речовини & Нафтопродукти \\
\hline 8 & Святошинський & $\mathrm{CO}, \mathrm{SO}_{2}, \mathrm{NO}_{2}$ & Завислі речовини & Нафтопродукти \\
\hline 9 & Подільський & $\mathrm{SO}_{2}, \mathrm{NO}_{2}$ & Завислі речовини & Нафтопродукти \\
\hline 10 & Солом'янський & $\mathrm{SO}_{2}, \mathrm{NO}_{2}, \mathrm{TU}$ & Завислі речовини & Нафтопродукти \\
\hline
\end{tabular}

Гранично допустима концентрація шкідливих речовин на територіях районів м. Києва інколи перевищує 15 од. Такі ділянки зареєстровані в Дніпровському, Солом'янському, Дарницькому та Голосіївському районах міста, тобто там, де 
розташовані досить потужні промислові підприємства. На всіх стаціонарних постах зазначених районів відзначається перевищення вмісту основних забруднюючих домішок - пилу, діоксиду сірки, оксиду вуглецю і діоксиду азоту.

Підвищення середньомісячного вмісту забруднюючих речовин у повітрі м. Києва спостерігається, як завжди, у теплий період року - 3 квітня по вересень. Найбільш суттєве зростання зафіксовано з червня по серпень, що пов'язано 3 підвищенням фотохімічних процесів в атмосфері при високій температурі повітря та інтенсивності сонячної радіації.

В грунтовому покриві районів м. Києва постійно фіксуються такі речовини, як ртуть, свинець, цинк, хром, нікель, мідь, барій, ванадій, вольфрам, марганець. Найбільше забруднення грунтів спостерігається в районі ТЕЦ-4, де вміст цинку перевищує фоновий рівень у 22 рази, АТ «Київгума» - відповідно у 8,5 раза, біля заводів Художнього скла та «Радар» (перевищення фонових значень вмісту свинцю в 3,5 раза, міді в 3-5 разів).

Антропогенне евтрофування та забруднення водних об'єктів та їх ресурсів в адміністративних районах м. Києва призводить до деградації великих та малих річок, водосховищ, озерних систем та до погіршення якості води, головною причиною чого $\epsilon$ скиди, що надходять у водойми 3 водозбору в результаті безвідповідальної діяльності промислових та комунальних підприємств.

Зважаючи на те, що мутагенність виявляється при значно нижчих концентраціях, ніж токсичність, а популяційно-генетичні наслідки іiі дії $\epsilon$ катастрофічними, виникає необхідність здійснення екологічного моніторингу iз застосуванням рослинних організмів як ефективних індикаційних систем забруднення довкілля (табл. 2).

Таблиця 2 - Інтегральний показник флуктуаційної асиметрії у вибірці

\begin{tabular}{|c|c|c|c|}
\hline $\begin{array}{c}\text { Район } \\
\text { дослідження }\end{array}$ & $\begin{array}{l}\text { Величина } \\
\text { у вибірці }\end{array}$ & $\begin{array}{l}\text { Показник } \\
\text { ФА }\end{array}$ & Характеристика \\
\hline Голосіївський & 0,051 & IV & Дуже забруднені райони \\
\hline Оболонський & 0,043 & II & $\begin{array}{l}\text { Рослини відчувають слабкий вплив } \\
\text { несприятливих факторів }\end{array}$ \\
\hline Шевченківський & 0,049 & III & Забруднені райони \\
\hline Дарницький & 0,057 & $\mathrm{~V}$ & $\begin{array}{l}\text { Вкрай несприятливі умови, рослини } \\
\text { знаходяться в дуже пригніченому стані }\end{array}$ \\
\hline Дніпровський & 0,057 & $\mathrm{~V}$ & $\begin{array}{l}\text { Вкрай несприятливі умови, рослини } \\
\text { знаходяться в дуже пригніченому стані }\end{array}$ \\
\hline Деснянський & 0,041 & II & $\begin{array}{l}\text { Рослини відчувають слабкий вплив } \\
\text { несприятливих факторів }\end{array}$ \\
\hline Печерський & 0,043 & II & $\begin{array}{l}\text { Рослини відчувають слабкий вплив } \\
\text { несприятливих факторів }\end{array}$ \\
\hline Святошинський & 0,043 & II & $\begin{array}{l}\text { Рослини відчувають слабкий вплив } \\
\text { несприятливих факторів }\end{array}$ \\
\hline Подільський & 0,042 & II & $\begin{array}{l}\text { Рослини відчувають слабкий вплив } \\
\text { несприятливих факторів }\end{array}$ \\
\hline Солом'янський & 0,055 & $\mathrm{~V}$ & $\begin{array}{l}\text { Вкрай несприятливі умови, рослини } \\
\text { знаходяться в дуже пригніченому стані }\end{array}$ \\
\hline
\end{tabular}

Встановлено, що показник ФА відображує деформацію взаємодії між рослинними організмами та навколишнім середовищем, а також виступає 
показником рівня екологічної небезпеки і $\epsilon$ найвищим у Дарницькому, Дніпровському та Солом'янському районах м. Києва, що підтверджують дані результатів фіксованих вимірювань. Рослинні насадження, що проростають у Подільському, Печерському, Деснянському та Оболонському районах, знаходяться в умовах слабкого антропогенного тиску, що в певній мірі позначається на всіх етапах їх онтогенезу. Було виявлено, що середній та високий рівень інтегрального показника порушення стабільності розвитку деревних насаджень спостерігаються в районах міста 3 підвищеною концентрацією оксидів азоту та вуглецю й діоксиду сірки, що дозволяє стверджувати про формування ділянок екологічного ризику, обумовлених забрудненням атмосфери.

\section{Висновки}

Встановлено, що території адміністративних районів м. Києва характеризуються низьким ступенем збереження й відновлення екологічних властивостей атмосферного повітря. При поєднанні результатів експрес-оцінки за показником ФА 3 даними фіксованих вимірювань, можна класифікувати урбоекосистеми за ступенем антропогенних змін цілого комплексу факторів, які є значущими під час формування специфічних властивостей міського середовища. Проведена біоіндикаційна оцінка дозволяє розробити ряд управлінських рішень і заходів для зменшення рівня екологічної небезпеки при збільшенні техногенного навантаження на урбоекосистеми. Отже, представлені дані будуть слугувати базисом для розроблення та обгрунтування комплексного підходу для підвищення рівня екологічної безпеки територій.

\section{СПИСОК ЛІТРАТУРИ}

1. Palmer A., Strobeck C. Fluctuating asymmetry as a measure of developmental stability: implications of non-normal distributions and power of statistical tests / Acta Zool. Fenn. 1992. V. 191. P. 57-72.

2. Velickovi M. Developmental stability in Tilia cordata leaves. Period biol. 2010. V. 112. № 3. P. 273-281

3. Shadrina E., Vol'pert Y. Evaluation of Environmental Conditions in Two Cities of East Siberia. Using Bio-indication Methods (Fluctuating Asymmetry Value and Mutagenic Activity of Soils). International Journal of Biology. 2015. V. 7. P. 20-32.

4. Broun L. Eco-Economy. New York: W. W. Norton\&Company. 2002. 334 p.

5. Скакальський О. Екологічний моніторинг у системі природоохоронної діяльності регіональної влади. Державне управління та місиеве самоврядування. 2015. Вип. 4. C. $152-162$.

6. Clarke G. Fluctuating asymmetry: a technique for measuring developmental stress of genetic and environment origin. Acta Zool Fenn. 1992. V. 191. P. 31-35.

7. Franiel I. Fluctuating asymmetry of Betula pendula Roth. leaves - an index of environment quality. Biodiv. Res. Conserv. 2008. V. 9-10. P. 7-10.

8. Loehle C. Challenges of ecological complexity. Ecological complexity. 2004. V. 1. P. 3-6. 9. Sakai K., Shimamoto Y. Developmental instability in leaves and flowers of Nicotiana tabacum. Genetics. 1965. V. 51. P. 801-813.

10. Захаров В. М. Асимметрия животных. М.: Наука, 1987. 215 с.

Стаття надійшла до редакиії 06.09.2019 і прийнята до друку після рецензування 17.09.2019 


\section{REFERENCES (TRANSLATED AND TRANSLITERATED)}

1. Palmer, A., \& Strobeck, C. (1992). Fluctuating asymmetry as a measure of developmental stability: implications of non-normal distributions and power of statistical tests. Acta Zool. Fenn, 191, 57-72.

2. Velickovi, M. (2010). Developmental stability in Tilia cordata leaves. Period Biol., 112(3), 273-281.

3. Shadrina, E., \& Vol'pert, Y. (2015). Evaluation of Environmental Conditions in Two Cities of East Siberia. Using Bio-indication Methods (Fluctuating Asymmetry Value and Mutagenic Activity of Soils). International Journal of Biology, 7, 20-32.

4. Broun, L. (2002). Eco-Economy. New York: W. W. Norton\&Company.

5. Skakal's'kyy, O. (2015). Ekolohichnyy monitorynh u systemi pryrodookhoronnoyi diyal'nosti rehional'noyi vlady. Derzhavne upravlinnya ta mistseve samovryaduvannya, (4), 152-162. (in Ukrainian).

6. Clarke, G. (1992). Fluctuating asymmetry: a technique for measuring developmental stress of genetic and environment origin. Acta Zool Fenn, 191, 31-35.

7. Franiel, I. (2008). Fluctuating asymmetry of Betula pendula Roth. leaves - an index of environment quality. Biodiv. Res. Conserv., 9-10, 7-10.

8. Loehle, C. (2004). Challenges of ecological complexity. Ecological complexity, 1, 3-6.

9. Sakai, K., \& Shimamoto, Y. (1965). Developmental instability in leaves and flowers of Nicotiana tabacum. Genetics, 51, 801-813.

10. Zakharov, V. M. (1987). Asimmetriya zhivotnykh. M.: Nauka. (In Russian).

The article was received 06.09.2019 and was accepted after revision 17.09.2019

\section{Барабаш Олена Василівна}

кандидат біологічних наук, доцент кафедри екології та безпеки життєдіяльності Національного транспортного університету

Адреса робоча: 01010 Україна, м. Київ, вул. М. Омеляновича-Павленка, 1

e-mail: el_barabash@ukr.net 